\title{
Pivampicillin Pamoate
}

National Cancer Institute

\section{Source}

National Cancer Institute. Pivampicillin Pamoate. NCI Thesaurus. Code C73835.

The pamoate salt form of a semisynthetic, orally active pivalate ester of ampicillin with antibacterial activity. Upon absorption, pivampicillin is hydrolyzed into its active form ampicillin by esterases. Ampicillin binds to and inactivates penicillin-binding proteins (PBPs) located on the inner membrane of the bacterial cell wall. Inactivation of PBPs interferes with the cross-linkage of peptidoglycan chains necessary for bacterial cell wall strength and rigidity. This interrupts bacterial cell wall synthesis and results in the weakening of the bacterial cell wall, eventually causing cell lysis. 